УДК 664.1.03

\title{
THE EFFICIENCY OF MODERN DEZINFECTANTS IN THE SUGAR BEET PROCESSING AFFECTED BY BACTERIA OF LEUCONOSTOC
}

\author{
N. Husyatynska, T. Nechypor \\ National University of Food Technologies
}

\begin{tabular}{|c|c|}
\hline Key words: & BSTRACT \\
\hline $\begin{array}{l}\text { Dextran } \\
\text { Mucous bacteriosis } \\
\text { Leuconostoc } \\
\text { Diffusion juice } \\
\text { Disinfectants }\end{array}$ & $\begin{array}{l}\text { In the article it is investigated the impact of dextran on the } \\
\text { technological quality of the diffusion and cleared juices. It is } \\
\text { confirmed that as a result of the presence of dextran the } \\
\text { indicator of sucrose content is distorted by direct pola- } \\
\text { rization method that leads to its overestimation compared to }\end{array}$ \\
\hline $\begin{array}{l}\quad \text { Article history: } \\
\text { Received 17.11.2017 } \\
\text { Received in revised form } \\
06.12 .2017 \\
\text { Accepted } 27.12 .2017\end{array}$ & $\begin{array}{l}\text { its actual value. It is established the high efficiency of } \\
\text { modern disinfectants on inhibition of the development of } \\
\text { slimeforming bacteria of Leuconostoc genus. It is confirmed } \\
\text { the possibility of their use in various manufacturing stages } \\
\text { of sugar beet production to prevent the development of }\end{array}$ \\
\hline $\begin{array}{l}\text { Corresponding author: } \\
\text { N. Husyatynska } \\
\text { E-mail: } \\
\text { npnuht@ukr.net }\end{array}$ & \\
\hline
\end{tabular}

DOI: $10.24263 / 2225-2924-2017-23-6-25$

\section{ЕФЕКТИВНІСТЬ СУЧАСНИХ ДЕЗІНФЕКТАНТІВ ПРИ ПЕРЕРОБЛЕННІ ЦУКРОВИХ БУРЯКІВ, УРАЖЕНИХ БАКТЕРІЯМИ РОДУ LEUCONOSTOC}

\author{
Н.А. Гусятинська, Т.М. Нечипор \\ Національний університет харчових технологій
}

У статті досліджено вплив декстрану на технологічну якість дифузійного та очищеного соків. Підтверджено, що в результаті наявності декстрану спотворюється показник вмісту сахарози за методом прямої поляризації, що призводить до його завищення порівняно з дійсним значенням. Встановлено високу ефективність сучасних дезінфікуючих засобів щодо пригнічення розвитку слизоутворювальних бактерій роду Leисопоstoc. Підтверджено можливість їх використання на різних технологічних стадіях бурякоиукрового виробництва для запобігання розвитку слизистого бактеріозу.

Ключові слова: декстран, слизистий бактеріоз, Leисоnostoc, дифузійний сік, дезінфікуючі засоби.

Постановка проблеми. Якість сировини визначає технологічний процес виробництва білого цукру. Проте існує ряд об'єктивних чинників, що впли- 
вають на зниження технологічних показників цукрових буряків унаслідок перебігу мікробіологічних процесів.

Найбільш небезпечним видом мікробного псування цукрових буряків $є$ слизистий бактеріоз, що спричиняється слизоутворювальними бактеріями роду Leuconostoc. Типовим представником слизоутворювальних бактерій, що зустрічаються на цукрових заводах, є Leuconostoc mesenteroides. Утворення декстрану бактеріями роду Leuconostoc mesenteroides відбувається в результаті розкладання сахарози (рис. 1), аналогічному ферментативній інверсії, за винятком того, що глюкоза полімеризується в декстран, а фруктоза використовується для живлення бактерій [1].

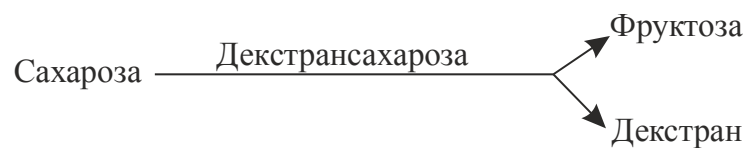

\section{Рис. 1. Синтез декстрану Leuconostoc mesenteroides iз сахарози}

Унаслідок ураження коренеплодів слизистим бактеріозом у буряковому соку утворюється декстран.

Декстран є поліглюканом, який змінюється в розмірі від низькомолекулярного (розчинний) до високомолекулярного (нерозчинний). Окрім того, розчинність декстрану залежить від структурної будови макромолекули: чим вищий вміст $\alpha-(1 \rightarrow 6)$ зв’язків, тим більша розчинність. I навпаки, чим вищий відсоток $\alpha-(1 \rightarrow 3)$ зв' язків у полімері, тим менша розчинність у воді (рис. 1) [1]. Саме наявність розчинного декстрану в соках i напівпродуктах цукрового виробництва спричинює не лише прямі втрати сахарози, але й створює значні проблеми у виробництві: зменшується ефективність очищення соку, погіршуються фільтраційно-седиментаційні властивості осаду, знижується швидкість випаровування, зменшується теплопередача тощо. Зрештою це призводить до уповільнення процесу кристалізації, збільшення тривалості уварювання утфелів, що спричинює зниження заводських потужностей [2].

Мета статті: дослідження впливу декстрану на технологічну якість дифузійного та очищеного соків, а також визначення ефективності сучасних дезінфікуючих засобів щодо слизоутворювальних бактерій роду Leuconostoc 3 метою їх подальшого застосування при виробництві цукру.

Матеріали і методи. Об’єктом досліджень був стерильний дифузійний сік, приготований у лабораторних умовах, оброблений чистою культурою бактерій L. mesenteroides. Термостатування здійснювали при температурі $37^{\circ} \mathrm{C}$ протягом 24 год. Визначення декстрану, молочної кислоти і нітритів проводили колориметричним методом [3]. Кількість бактерій L. mesenteroides визначали за методом Коха шляхом висіву на поживне середовище МПА 3 $10 \%$ сахарози.

У ході досліджень використовували такі дезінфекційні засоби з робочими концентраціями по діючій речовині: засіб 1 і засіб $2-0,001,0,002,0,003$ та 0,004\%, засіб $3-0,0005,0,00075,0,001,0,002$ та 0,004\%, засіб $4-0,0002$, 0,0004, 0,0008 та 0,001\%, засіб $5-0,001,0,002,0,004$ та 0,008\%. Відповідно: засіб 1 - основні діючі речовини: полігексаметиленбігуанідин гідро хлорид 
$15-20 \%$; натрію поліакрилат $0,5-1,0 \%$; засіб $2-$ діючою речовиною $\epsilon$ полігексаметиленбігуанідин гідро хлорид $15 \%$; засіб 3 - діючою речовиною $\epsilon$ четвертинні амонієві сполук у кількості $40 \%$; засіб 4 - діючою речовиною $\epsilon$ натрієва сіль дихлорізоціанурової кислоти - 80,0\%; засіб 5 - діючою речовиною є надоцтова кислота в кількості $12 \%$ та пероксид водню - $18 \%$.

Для визначення чутливості мікроорганізмів до дії дезінфікуючих засобів використовували метод «лунок у товщі агару». Культивування мікроорганізмів проводили на поживному середовищі МПА з додаванням 10\% сахарози 3 внесеною чистою культурою L. mesenteroides. Висновки про ефективність засобів робили за наявністю та розмірами зони затримки росту мікроорганізмів. Відсутність зони затримки росту вказує на те, що досліджувана культура нечутлива до дії даного антимікробного засобу. При діаметрі зони до 15 мм вважають, що мікроорганізми мають малий ступінь чутливості до досліджуваного засобу, діаметр зони від 15 до 25 мм вказує на середній ступінь чутливості. Наявність зони діаметром більше 25 мм свідчить про високий ступінь чутливості мікроорганізмів до даного антимікробного засобу.

Результати і обговорення. Утворення декстрану бактеріями роду Leuconostoc може виступати індикатором їх розвитку. Накопичення вмісту декстрану при термостатуванні проби дифузійного соку, інфікованого культурою L. mesenteroides, зображено на рис. 2.

Необхідно зазначити, що при термостатуванні проб дифузійного соку кількість клітин тест-культури збільшилася практично на два порядки порівняно 3 початковим вмістом і становила $4,8 \cdot 10^{7} \mathrm{KУО} / \mathrm{cm}^{3}$ після 24 год культивування, а вміст декстрану через 24 год збільшився у 20 разів порівняно 3 початковим значенням.

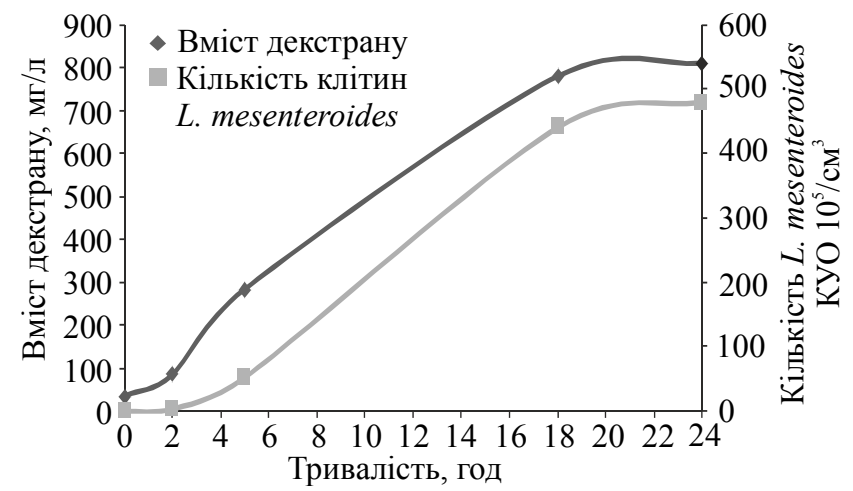

Рис. 2. Накопичення декстрану при термостатуванні проби дифузійного соку, інфікованого культурою L. mesenteroides

Таким чином, проведені дослідження показали, що у разі розвитку слизоутворювальних бактерій у дифузійному соку спостерігається інтенсивне накопичення декстрану, що корелює зі збільшенням кількості клітин тест-культури L. mesenteroides.

Також відомо [4], що результатом життєдіяльності бактерій роду Leuconostoc $є$ накопичення молочної кислоти. Тому доцільним було визначення інтенсивності накопичення даної кислоти у дифузійному соку за розвитку 
тест-культури L. mesenteroides. Результати досліджень щодо вмісту молочної кислоти в інфікованих пробах наведено на рис. 3.

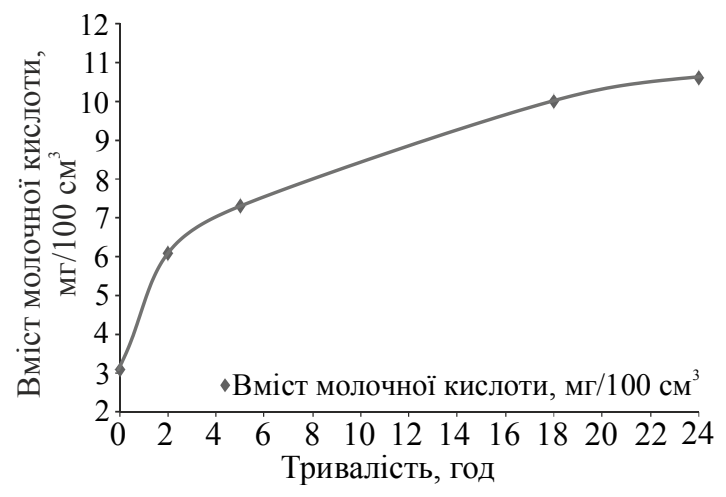

Рис. 3. Вміст молочної кислоти у дифузійному соку, інфікованому культурою $L$. mesenteroides

Так, у пробі соку з L. mesenterioides після термостатування при $37^{\circ} \mathrm{C}$ протягом перших 2 год вміст молочної кислоти зріс на 50\%, через 18 год - на $60 \%$, а через добу — зріс в 3,5 раза і становив $10,63 \mathrm{мг} / 100 \mathrm{~cm}^{3}$ порівняно 3 початковим вмістом молочної кислоти - 3,07 мг/100 см${ }^{3}$.

3 метою визначення впливу вмісту декстрану в дифузійному соку на технологічну якість очищеного соку нами було проведено відповідні дослідження. Для досліджень використовували кондиційні коренеплоди середніх строків зберігання, а також коренеплоди повністю вражені слизистим бактеріозом. Відповідно, одержували дифузійний сік за типовим способом окремо з кожної групи коренеплодів. У проби контрольного дифузійного соку (з кондиційних коренеплодів) вносили визначену кількість дифузійного соку 3 декстраном i проводили процес очищення дифузійного соку за допомогою дефекосатурації. Результати експериментальних досліджень (табл. 1, 2) свідчать про значний негативний вплив приросту вмісту декстрану в дифузійному соку на технологічну якість напівпродуктів бурякоцукрового виробництва.

Таблиця 1. Вплив декстрану на технологічну якість дифузійного соку

\begin{tabular}{|c|c|c|c|c|c|}
\hline \multirow{2}{*}{ Технологічні показники дифузійного соку } & \multicolumn{5}{|c|}{$\begin{array}{c}\text { Супінь ураження коренеплодів } \\
\text { слизистим бактеріозом, \% }\end{array}$} \\
\cline { 2 - 6 } & 0 & 10 & 15 & 20 & 25 \\
\cline { 2 - 6 } & \multicolumn{5}{|c|}{ Вміст декстрану, мг/л } \\
\cline { 2 - 6 } & 0 & 240 & 360 & 480 & 600 \\
\hline $\mathrm{pH}_{20}$ & 6,28 & 6,2 & 6,18 & 6,23 & 6,3 \\
\hline Вміст молочної кислоти, мг/100 см ${ }^{3}$ & 4,74 & 5,1 & 5,7 & 5,8 & 6,1 \\
\hline Вміст нітритів, мг/дм & 7,63 & 7,92 & 8,04 & 8,1 & 8,3 \\
\hline Вміст пектинових речовин, \% на $100 \mathrm{CP}$ & 1,33 & 1,72 & 1,98 & 2,15 & 2,39 \\
\hline Вміст високомолекулярних сполук, \% на $100 \mathrm{CP}$ & 2,6 & 3,48 & 3,88 & 4,96 & 5,47 \\
\hline
\end{tabular}

Таким чином встановлено, що при збільшенні ступеня ураження коренеплодів слизистим бактеріозом не тільки підвищується вміст декстрану в 
дифузійному соку, але й відбувається ряд біохімічних процесів, унаслідок чого в соку накопичуються продукти розкладання, зокрема розчинні пектинові речовини, молочна кислота, нітрити, які негативно впливають на подальші стадії виробництва цукру.

Необхідно зазначити, що внаслідок вмісту декстрану, який є оптично активною речовиною $[\alpha]{ }_{D}^{20}=+230^{\circ}-233^{\circ}$, у буряковій стружці, буряковому та дифузійному соках спотворюється показник вмісту сахарози за методом прямої поляризації (табл. 1), що призводить до його завищення і негативно впливає на технологічній облік і контроль у виробництві. Так, у середньому спостерігалося завищення показника вмісту сахарози в дифузійному соку за методом прямої поляризації на $0,15-0,2$ од на 100 мг дектрану порівняно 3 методом інверсійної поляризації. Це пояснюється тим, що інверсійно-поляриметричний метод з інвертуванням соляною кислотою дає змогу певною мірою виключити вплив інших оптично активних речовин на результати визначення сахарози. Метод заснований на здатності сахарози під впливом кислот перетворюватися на лівообертаючу суміш глюкози і фруктози (інвертний цукор). При цьому припускають, що інші оптично активні речовини не змінюють свою обертальну здатність після інверсії. Таким чином, зміна обертання площини поляризації після інверсії залежить тільки від кількості сахарози, наявної в даному продукті [5].

Таблиия 2. Вплив вмісту декстрану на зниження показника масової частки сахарози дифузійного соку

\begin{tabular}{|c|c|c|c|c|c|}
\hline Технологічні показники дифузійного соку & \multicolumn{3}{|c|}{ Вміст декстрану, мг/л } \\
\cline { 2 - 6 } & 0 & 240 & 360 & 480 & 600 \\
\hline Масова частка сухих речовин, \% & 13,5 & 13,2 & 13,6 & 13,3 & 13,2 \\
\hline Чистота, \% & 12 & 11,6 & 11,2 & 10,8 & 10,5 \\
\hline Масова частка сахарози (за методом прямої поляризації), \% & 88 & 87,8 & 82,4 & 81,2 & 79,5 \\
\hline Масова частка сахарози (за методом інверсійної поляризації), \% & 12 & 11,2 & 10,65 & 10,0 & 9,2 \\
\hline Чистота, \% & 88 & 84,8 & 78,3 & 75,2 & 69,7 \\
\hline $\begin{array}{c}\text { Середне зниження показника масової частки сахарози на 100 мг } \\
\text { декстрану }\end{array}$ & $-16,16$ & 0,153 & 0,166 & 0,21 \\
\hline
\end{tabular}

Окрім того, наявність декстрану призводить до підвищення в'язкості продуктів, погіршення фільтраційних властивостей соків у процесі очищення, збільшення тривалості кристалізації цукру і підвищення втрат цукру в мелясі [6]. Так, за нашими дослідженнями встановлено [7], що за вмісту декстрану 600 мг/л забарвленість соку другої сатурації збільшується в 5 разів порівняно 3 контрольним соком II сатурації. Підтверджено, що підвищення вмісту декстрану в дифузійному соку погіршує седиментаційні властивості осаду при дефекосатураційному очищенні. Так, за вмісту декстрану 240 мг/л у дифузійному соку знижується швидкість осадження осаду соку I сатурації в 2 рази порівняно 3 контрольною пробою і становить $1,36 \mathrm{~cm} / \mathrm{xв}$, в той час як швидкість осідання в контрольній пробі становить 2,8 см/хв.

Таким чином, перероблення буряків, уражених слизистим бактеріозом, призводить до ряду негативних наслідків, тому важливим завданням $€$ запобі- 
гання розвитку слизоутворювальних бактерій у дифузійному апараті, мезгоуловлювачах жомопресової води та дифузійного соку, збірниках жомопресової води, оскільки саме на цих ділянках у більшому ступені може спостерігатися розвиток мікробіологічних процесів.

Тому з метою запобігання інтенсивного розвитку мікробіологічних процесів доцільно використовувати дезінфікуючі засоби. Наразі існує широкий спектр дезінфікуючих засобів, проте їх якість не завжди задовольняє виробництво 3 точки зору як погіршення якості соків та напівпродуктів, так і низької ефективності дії щодо контамінуючої мікрофлори.

Нами проведено ряд досліджень 3 метою встановлення ефективності застосування сучасних дезінфікуючих засобів щодо пригнічення розвитку слизоутворювальних бактерій роду Leuconostoc. Результати досліджень чутливості слизоутворювальних бактерій L. mesenteroides до дії дезінфікуючих засобів представлено на рис. 4 та 5.

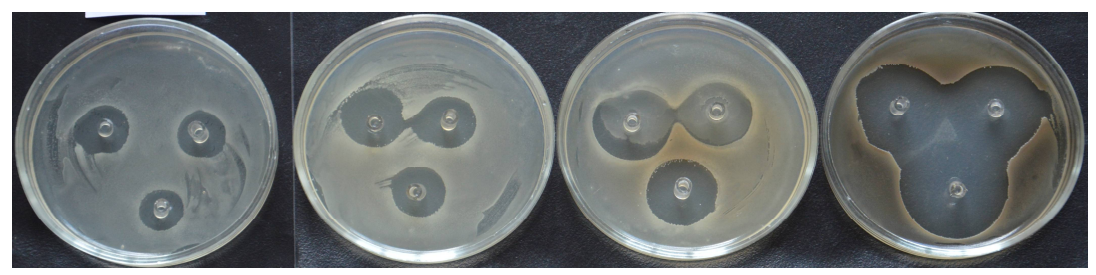

Рис. 4. Дія засобу 5 з концентраціями 0,001, 0,002, 0,004 та 0,008\% на бактерії L. mesenteroides

Слід відзначити, що у разі застосування Засобу 4 спостерігалися не тільки чіткі зони затримки росту, але й пригнічення росту культури по всій чашці порівняно з контролем.

До особливих характеристик розвитку слизистого бактеріозу, а також «кльоку» слід віднести стійкість бактерій унаслідок утворення зовнішньої декстранової капсули до ряду хімічних засобів, дії високої температури та інших фізико-хімічних впливів [6].

Аналіз результатів проведених досліджень (рис. 5) свідчить про високу ефективність досліджуваних дезінфікуючих засобів щодо слизоутворювальних бактерій L. mesenteroides, які часто виявляють у сировині, технологічній воді, напівпродуктах бурякоцукрового виробництва.

Наявність високого бактерицидного ефекту надає можливість рекомендувати досліджувані засоби для обробки транспортерно-мийної води, води для ополіскування коренеплодів, для обробки сокостружкової суміші під час екстрагування сахарози з бурякової стружки та на інших ділянках виробництва, які потребують дезінфекції.

Враховуючи проведені дослідження, оптимальні витрати досліджуваних засобів щодо слизоутворювальних бактерій роду Leuconostoc такі: засіб 1 і 2 $0,002-0,0035 \%$; засіб $3-0,001-0,002 \%$; засіб $4-0,0004-0,0008 \%$; засіб $5-$ $0,004-0,006 \%$ до маси продукту. Дезінфекцію сокостружкової суміші у дифузійному апараті слід здійснювати шляхом періодичного або безперервного введення одного із досліджуваних дезінфектантів. Таким чином, засоби 1 і 2 за періодичного способу вводяться у 2-4 точки дифузійного апарата та 
у збірник жомопресової води з розрахунку загальних витрат $0,0005-0,0035 \%$ до маси перероблених за добу буряків. Рекомендовані витрати при переробленні кондиційних буряків $0,0005-0,0015 \%$ (5-15 г/тону буряків). У разі потреби (за наявності розвитку слизистого бактеріозу, значного приросту вмісту молочної кислоти ін.) витрати засобу можуть становити до $0,0035 \%$ до маси буряків (30-35 г/тонну буряків).

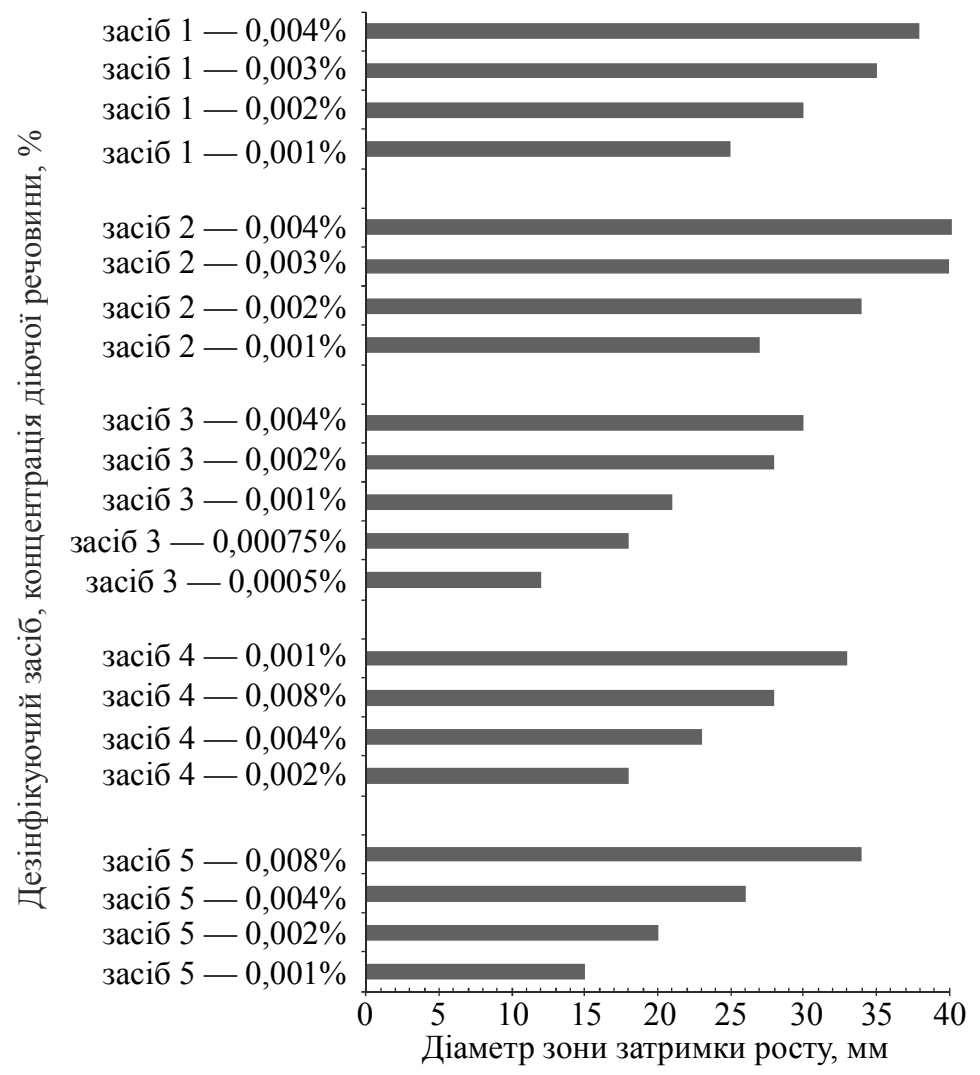

Рис. 5. Ступінь чутливості слизоутворювальних бактерій L. mesenteroides до дії дезінфікуючих засобів за методом «лунок у товщі агару»

Для засобу 3 рекомендується періодичний спосіб введення у $2-4$ точки дифузійного апарата та у збірник жомопресової води 3 розрахунку витрат $0,0004-0,0015 \%$ до маси перероблених за добу буряків (4-15 г/т буряків). Періодичність введення складає 4-8 разів на добу і залежить від якості буряків, що переробляються. Рекомендовані витрати при переробленні кондиційних буряків $0,0004-0,0015 \%$ (4-15 г/тонну цукрових буряків). У разі потреби (за наявності розвитку слизистого бактеріозу, значного приросту вмісту молочної кислоти тощо) витрати засобу можуть становити до $0,002 \%$ до маси буряків (20 г/тонну буряків).

Для засобу 4 рекомендується періодичний спосіб введення у 2-4 точки дифузійного апарата та у збірник жомопресової води з розрахунку витрат $0,00005-0,0002 \%$ до маси перероблених за добу буряків. Періодичність 
введення складає 4-8 разів на добу і залежить від якості буряків, що переробляються. Рекомендовані витрати при переробленні кондиційних буряків $0,0001-0,00015 \%(1-1,5$ г/тонну (1-1,5 кг на тис. т) цукрових буряків). У разі потреби (за наявності розвитку слизистого бактеріозу, значного приросту вмісту молочної кислоти ін.) витрати засобу можуть становити до 0,0002\% до маси буряків (2 г/тонну (2 кг на тис. т) буряків).

Для засобу 5 рекомендується періодичний спосіб введення у $2-4$ точки дифузійного апарата та у збірник жомопресової води з розрахунку витрат витрат $0,0005-0,002 \%$ до маси перероблених за добу буряків (5-20 г/т буряків). Періодичність введення складає $4-8$ разів на добу і залежить від якості буряків, що переробляються. Рекомендовані витрати при переробленні кондиційних буряків 0,0005-0,0015\% (5-15 г/тонну цукрових буряків). У разі потреби (за наявності розвитку слизистого бактеріозу, значного приросту вмісту молочної кислоти ін.) витрати засобу можуть становити до 0,002\% до маси буряків (20 г/тонну буряків).

\section{Висновки}

1. Встановлено, що у разі розвитку слизоутворювальних бактерій роду Leuconostoc у дифузійному соку спостерігається інтенсивне накопичення декстрану, вміст якого корелює 3 кількістю клітин слизоутворювальних бактерій.

2. Підтверджено, що внаслідок накопичення вмісту декстрану в буряковій стружці, буряковому та дифузійному соках спотворюється показник вмісту сахарози за методом прямої поляризації, що призводить до його завищення i негативно впливає на технологічний облік і контроль у виробництві. Встановлено, що завищення показника вмісту сахарози за поляриметричним методом на кожні 100 мг дектрану становить 0,15-0,2 од.

3. Визначено рекомендовані витрати ряду сучасних засобів щодо пригнічення розвитку слизоутворювальних бактерій роду Leuconostoc у цукробуряковому виробництві: засіб 1 та $2-0,002-0,003 \%$; засіб $3-0,001-0,002 \%$; засіб $4-0,0004-0,0008 \%$; засіб $5-0,004-0,006 \%$.

\section{Лiтература}

1. Soliman El-Sayed Ali Abdel-Rahman Investigations on the influence of dextran during beet sugar production with special focus on crystal growth and morphology: dissertation doctor of engineering / Soliman El-Sayed Ali Abdel-Rahman — Berlin, 2007. - 109 p.

2. Rauh J.S. Analyzing dextran in the sugar industry: A review of dextran in the factory and a new analytical technique / Rauh J.S., Cuddihy J.A., Falgout R.N. // $30^{\text {th }}$ Biennial Meeting American Society of Sugar Beet Technologists at Orlando. — 1999. — P. $29-40$.

3. Купчик М.П. Технологія цукристих речовин. Лабор. практикум / М.П. Купчик, Л.П. Рева, Н.І. Штангеєва та ін. — Київ : НУХТ, 2007. — 393 с.

4. Белостоикий Л.Г. Указания по ведению микробиологического контроля свеклосахарного производства. — Киев : ВНИИСП, 1984. - 164 с.

5. Методические указания к выполнению учебно-исследовательских работ по спецконтролю сахарного производства для студентов специальности 27.03 всех форм обучения / Сост. М.И. Барабанов, А.П. Козявкин, Н.И. Штангеева. - Киев : КТИПП, 1990. — 56 с.

6. Гусятинська Н.А. Актуальні питання мікробіологічного контролю у виробництві цукру / Цукор України. — 2014. — № 6(102). - С. 21-32.

7. Гусятинська Н.А. Технологічні аспекти перероблення буряків, уражених слизистим бактеріозом / Н.А. Гусятинська, Т.М. Нечипор // Цукор України. — 2016. — № $11-$ 12(131-132). - C. 53-58. 